\title{
An African's faith: Discourse and disclosure in selected works by Sindiwe Magona
}

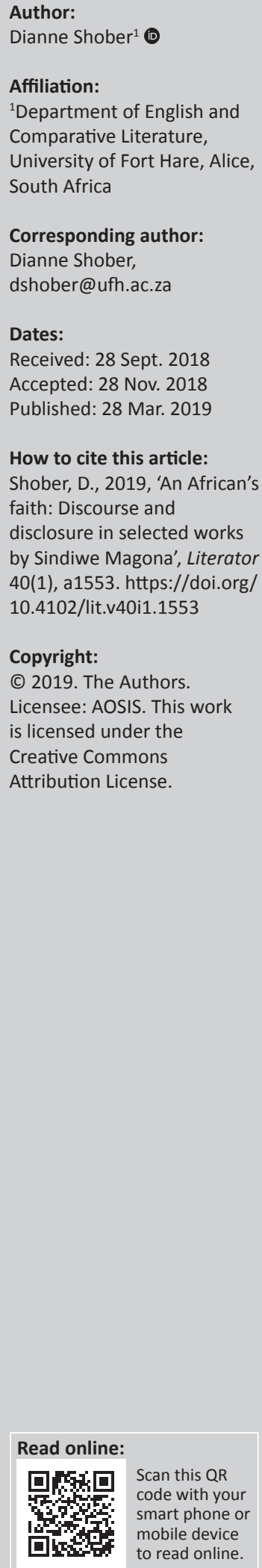

The recent attention to decolonisation in academia and other facets of the sociopolitical landscape has encouraged many to re-examine their tenets of faith and their methods of incorporating personal expressions of spirituality into their decision-making processes. The significance of faith practices for South Africans as they manoeuvre the challenges of navigating the post-apartheid context has been acknowledged across a number of disciplines, including law, education and healthcare. Yet for decades, South African writers have seamlessly included religious thought and practice into their works, evidencing the subtle influence of faith and tradition in their prose. For many, their religious faith has been vital to their identity development and cultural expression, and synonymous with their liberation. This article examines these metaphoric realities in the cohesive interplay of African traditions and western Christianity in the oeuvre of recognised black South African writer Sindiwe Magona.

Keywords: Spirituality; Christian faith; traditional religion; literature; South African literature; culture; expressions of faith; liberating theologies; identity.

\section{Introduction}

The Huffington Post South Africa (Davies 2017), in anticipation of the Christian celebration of Easter, devoted a series of articles to the spiritual journey of South Africans. They offered that: 'Against the backdrop of a renewed wave of thought around decolonisation, a new generation are rediscovering their traditional beliefs, while some are reconciling with Christianity' (Davies 2017:n.p.). A major study of the religious perspectives of sub-Saharan Africans discovered similar findings and found significant advantages to this pursuit of faith, stating:

\footnotetext{
... religion is not so much a source of conflict as a source of hope in sub-Saharan Africa, where religious leaders and movements are a major force in civil society and a key provider of relief and development for the needy, particularly given the widespread reality of failed states and collapsing government services. (Lugo 2010:n.p.)
}

The impact of religious thought and practice of our past president and Nobel laureate Nelson Mandela was investigated by an article by Verashni Pillay (2013). She noted that Mandela's reserved faith expresses the political motivation of the internationally respected leader to promote reconciliation in his nation torn by centuries of racial and religious conflict while maintaining a personal, albeit muted, expression of Christian commitment. Methodist bishop and friend Malusi Mpumlwana states:

When he [Mandela] confirmed his own faith as a Christian, he always said he was careful not to say that too loudly because of his commitment to an interfaith experience in South Africa. (Pillay 2013)

Graham Duncan, professor of theology at the University of Pretoria, acknowledges Mandela's non-partisan approach:

He made a concerted effort, certainly in the casting of the constitution, to make sure there was an entirely new dispensation that will never embrace one faith or one segment of faith. (Pillay 2013)

Nonetheless, Mandela openly voiced his respect for the religious influence that influenced his life and work: 'Without the church, without religious institution, I would never have been here today ... Religion was one of the motivating factors in everything we did' (Pillay 2013).

Current research suggests that religious thought and practice continues to be a serious consideration in the minds and actions of many South Africans. Jerry Pillay (2017) notes that postapartheid South African churches seek to encourage the activity of faith in the daily lives of their congregants, while some members express disappointment that the Church has not been engaged 
enough in establishing a new democratic nation. Nonetheless, John Klaasen (2016) argues that faith is instrumental in 'the formation of identity and that faith creates the space for cohesive coexistence'. He further contends that ' $[t]$ he Christian faith, when viewed as narrative, creates space and time for perceived differences and alienations to coexist'. Although Pamela King (2003) asserts that religion and spirituality positively affects the identity development of youth, a 2013 study by Arieka Brittian, Nina Lewin and Shane Norris, which investigated South African youths' perception of religion, observed that 'religious beliefs and practices often overlapped with cultural behaviors'. While recognising the influence of Christian faith expressions in youth development, these researchers also noted the guidance provided by African traditional religion, which they describe as 'a set of beliefs, customs, and practices indigenous to Southern Africa', which is 'constructed around fluid oral traditions that manifest as a set of interacting practices, worldviews, and beliefs that create multiple life worlds' (Brittian, Lewin \& Norris 2013). Anderson (2003) qualified this definition by specifying that it involves an adherence to the guidance and direction offered by ancestors, the significance of dreams, and ceremonial rites to prevent malevolent forces seeking to harm one's health and safety.

Thus, these life-giving forces of faith have been such an integral expression of an African's existence that they have meaningfully woven their way into works of literature, as this quote illustrates:

African writers of fiction use the genre to enter into dialogue with African and European religious traditions alike ... For the most part, African fiction in which religion is a significant theme works out issues of colonial and post-colonial (dis)empowerment, and features not only inter-religious tensions but also conflicts between religion and secular forces often imperfectly understood. (Joseph 2005)

However, David Levey in his 2007 article entitled 'Religion, literature and identity in South Africa: The case of Alan Paton' contends that insufficient research has been conducted on the religious inference offered by South African English writers. Perhaps in answer to this assertion, more scholarly attention has been given to the discussion of religious faith expressed by South African writers (Apostolides 2016; Cruywagen 2016; Marais \& Stobie 2014; Shober 2014, 2017). This article seeks to explore the dual elements of Christian and African traditional religion that South African writer Sindiwe Magona incorporates into her autobiographies, poetry and fictional works as metaphoric realities of her identity formation, cultural expression and liberation theology.

\section{Spirituality in Magona's oeuvre}

The life writings of Sindiwe Magona, South African author, inspirational speaker, social activist, poet and playwright, exhibit thematic representations of her African spirituality as she writes of her gender and political enslavement to her achievement of self-actualisation during her exile and return.
Indeed, Njoroge and Dube (2001) argue that African women writers seek to create liberating theologies through their autobiographies and storytelling. Jacob Olupona, professor of indigenous African religions at Harvard Divinity School and professor of African and African-American studies at Harvard's Faculty of Arts and Sciences, explains the ubiquitous integration of faith in his definition of African spirituality: 'African spirituality simply acknowledges that beliefs and practices touch on and inform every facet of human life, and therefore African religion cannot be separated from the everyday or mundane' (Chiorazzi 2015). This is a definition represented by Magona's seamless integration of faith practices in her daily life. Magona's spiritual and cultural rootedness enables her to write with refreshing and candid honesty of the perils facing young black women growing up in an impoverished and racially segregated environment. In her second novel, aptly titled Beauty's Gift, she writes:

God knew the African woman was going to have a very, very hard life. That is why He gave her skin as tough as Mother Earth herself. He gave her that tough, timeless skin so that her woes would not be written all over her face, so that her face would not be a map of her torn and tattered heart. (Magona 2008:1)

Martin (1993), in her article entitled 'Biblical theodicy and black women's spiritual autobiography', acknowledges the significance of authoring one's faith as a tool in enduring and overcoming discrimination's disfigurement:

Black spiritual autobiographies functioned - for both women and men - as a medium through which they could document the power of spiritual healing to effect some relief from the powerfully oppressive winds of racial denigration. They also provided a vehicle through which their authors could gain literary power and authority in the language of the dominant culture. (p. 21)

In her autobiographical and fictional works, Magona creates tenacious female characters (Mandisa in Mother to Mother 1998; Beauty and Amanda in Beauty's Gift [Magona 2008] and Shumikazi in Chasing the Tails of My Father's Cattle [Magona 2015]), who, like her, underpin their efforts to overcome life's degradations through nurturing their spirituality. Fellow South African writer Lauretta Ngcobo also uses spiritual metaphors to describe the longing for liberation:

But I tell you, as the prophet Ezekiel once prophesied, the dried bones of these men and women who have died will yet live. The God of Abraham and the god of our ancestors will breathe life into our nation and raise a new army which will arise and fight the evil on this land. (Ngcobo 1990:48)

Likewise, many of Magona's works are interspersed with proverbs from both isiXhosa and Christian traditions, gently blending the richness of these belief systems into the lives of her characters and the themes of reflexivity and social criticism that she sensitively explores. For example, in her first autobiographical work, To My Children's Children (1990:5), she writes that as a youngster in the rural homestead they concluded the evening meal with prayers after which followed a rousing time of campfire tales, iintsomi, in which her grandmother related stories of African ogres and princes, the villains and the virtuous. 
She also identifies her father as a lay preacher of the Anglican Church and explains his spiritual guidance of his family, thus:

As soon as a child could speak, in my father's house, that child was taught the Lord's Prayer. After the evening meal, evening chores and some family pleasantries, everyone was rounded up for evening prayer. Father's booming voice would announce the hymn to be sung at the onset of prayer. Following the singing, the children standing huddled together, arms folded and eyes closed, would recite the Lord's Prayer. (Magona 1990:55)

This recitation would be followed by a prepared litany of requests for the safety and protection of family and friends near and far. However, in many African homes the assurance that uThixo would provide sufficient protection from every manner of evil spirit sent by ancestors, jealous family members or spiteful neighbours was never overwhelming enough not to seek additional assistance from traditional spiritual and medicinal resources (Magona 1990:65). Es'kia Mphahlele acknowledges the living presence of African tradition in the heart of every black South African:

About eight out of every ten educated Africans, most of whom are also professed Christians, still believe firmly in the spirits of their ancestors. We don't speak to one another about it among the educated. But when we seek moral guidance and inspiration and hope, somewhere in the recesses of our being, we grope for some link with those spirits. (Mphahlele 1959:54-55)

In the same manner, Magona confesses a belief in Christianity and practices its moral principles as evidenced in her works, but she also respects African traditional religion, warning that as 'we scrambled to be civilized and westernized and Christianized $[i] n$ the process we lost ourselves. We lost our beautiful and constructive traditions' (Koyana 2004:182). Throughout her works, Magona provides a subtle yet profound interplay between Christian and African traditions, uniting the two as a delicate stencil that provides a didacticism to her material. In each work, she carefully explains unique isiXhosa traditions with which the uninformed reader would be unfamiliar, traditions such as marriage (Magona 1990:108) and funeral customs (pp. 60-62), igqirha's (the witch doctor's) protective incisions (p. 57), rites of passage (pp. 69-71) and dogmatic spousal authority (p. 152).

For instance, Magona interjects in her first autobiography many incidents from her childhood of the assistance that her parents sought to secure fortification against adversity and illness, many of which were painful and frightening. She recounts:

Incision was said to be the most potent weapon against witchcraft. Igqirha, a witch doctor, or ixhwele, a medicine man, having been invited by father, would appear at our doorstep, unexpectedly for us children. (Magona 1990:57)

She proceeds to describe the complex process:

Razor in hand, he would take a victim and place him or her facing him. Starting at the top and working his way swiftly downwards, he displays precision many a butcher would envy: again and again the blade slashes ... Between forty and sixty incisions, each cut into at least twice. Then the witchdoctor would rub the jet-black burning powder. His instructions, terse and gruff: 'Do not wash for two days'. (p. 58)

The inserted powder ensured that the wounds did not close together smoothly and the etchings would remain permanent reminders of the witch doctor's and parent's efforts to withstand any harmful onslaught from malevolent forces. However, the cost in the earthly realm was often severe. Schoolmates mocked them when they witnessed the incisions, ridiculing them for returning to practices declared 'barbaric' or 'backward' by the white people, an attitude mimicked by westernised black people. Magona explains the confusion and division this social binary created: 'This straddling of two worlds, the world of school and "civilization" and the world of ancestor worship, witchdoctors, and traditional rites, often created disagreements in our home' (Magona 1990:59). For instance, the children received various scientific and hygienic lessons in their classes at school, but attempts to introduce them into the home were derided by their mother. When the children attempted to convince their mother of the veracity of the information by reminding her that they were already protected by the witch doctor's medicines, she warned them not to invite disaster. Traditional influences far outweighed any questionable knowledge offered by white unbelievers. Linda Thomas (1997) states that:

The rituals of healing ... were a means for the African community to claim autonomy through symbol systems that used both indigenous African and Christian elements. These creolized rituals were counterhegemonic devices that Africans used to signal their disdain for oppressive dominant power structures and to claim their own power. The rituals were the African community's way of turning the wilderness experience of apartheid into a positive struggle for self-determination and confronting 'the negative with claims to a great indigenous past that included God, Spirit, the ancestors, and historical knowledge about survival'. (p. 68-69)

Thus, the marrying of these two spiritual disciplines and the bridging of these supernatural forces were constantly aligned. When Magona's aunt dies unexpectedly, her mother blames witchcraft: 'They waited just until my back was turned, and then the filthy witches did their dirty deed'; yet she is assured that the Christian God will provide comfort and dispense justice (Magona 1990:65). By incorporating traditional knowledge systems with Christian beliefs, the African woman seeks to empower herself to activate the dynamisms and practices available through both. This duality of spiritual forces is a significant girder uniting western and African ideologies and one that Magona interposes into all of her works. Beya (2001) agrees, explaining:

For [the African religious woman] the meaning of religious life is a question of fidelity to God and to the cultural values of life giving, of family solidarity, or responsibility, and of integration into the milieu. (p. 198)

The recognition of the accepted union of African and western ideologies is receiving validation in all life processes, whether 
professional or personal, as indicated in an article by Ayiedun and Ordor (2016:155-173) entitled 'Integrating the traditional with the contemporary in dispute resolution in Africa', which explores the potential, favourable duality of culturally sanctioned dispute methodologies with current customary law practices. This is echoed in an article by Andre de la Porte (2016), who champions the integration of faith-based compassion with 'holistic people-centred healthcare in South Africa'.

Magona recounts further participation in the connection between African and western spiritualism in her adult life. When she was reinstated into a position of economic and social significance by resuming her teaching position, she found time to reflect and rediscover her spiritual interests. In response to that call, she joined the Anglican Church, completing the necessary 'restoration' classes designed for single mothers. This religious reinstatement enabled her to have her children baptised, an important rite that Magona had felt remiss in completing. These events coincided with her mother's decision to enter training to become a witch-doctor, an activity that brought a crisis of conscience to Magona. As an educated woman, newly restored to an acceptable social status, Magona was initially aghast that her mother would be responsible for 'dragging [her] backwards with her barbaric beliefs' (Magona 1992:75). Yet, this face-toface encounter with African tradition enabled Magona to re-examine her own apartheid-like narrow-mindedness, a self-reflective process that has helped her to act as a bridge builder between traditions and people groups. She writes:

I am proud of Mother, for she has travelled very far in her life's journey. And being a witchdoctor [traditional healer] is just one more way in which she has amazed me. (Magona 1992:76)

By embracing her mother's calling as a traditional healer, Magona removes the western veil and missionary taboo. By her willingness to share some of the rituals of the forbidden, secret world of African tradition, she acts as a cultural conduit, removing the 'otherness' often associated with it by a western reader, and her own process of acceptance encourages the reader to engage with it positively as well. She writes:

I learned some of the rituals of the witchdoctors [traditional healers]; the way they address one another to show rank among themselves, which ancestors are invoked, in what order, and for what purpose; what the finery they wear signifies; and a host of other things. I came to know and admire the discipline and code of conduct witchdoctors [traditional healers] live by. (Magona 1992:76)

Through her literary revelation she smoothly traverses western Christianity and traditional healing by becoming the bridge herself between these two seemingly conflicting traditions when, in the one instance, she faithfully recites the Psalms at her restoration classes and, in the other, enthusiastically beats the drum at her mother's dances (Magona 1992:75). Gwendolyn Mikell (2010) acknowledges the meshing of these spiritual influences, especially for the African woman:
In the contemporary churches and new religions, African women have been bridge figures who continually retied urban culture to its African cultural base, further syncretising Christianity and African religious ideas. (p. 26)

Yet these did not always allow for a smooth transitioning.

One of the detriments of Magona's rigid spiritual instruction was the perceived absence of grace and the inculcation of condemnation intoned by her Christian teaching on personal responsibility. When at the cusp of her career she found herself pregnant, her unborn child fathered by a destitute migrant labourer, guilt consumed her. Added to this was her decision to marry this financially and educationally inadequate husband of whom her parents and extended family disapproved. Crippled by fear and shame, Magona succumbed to the African woman's double oppression wrought by the spiritual legacy of apartheid and patriarchy. 'It was natural,' Magona states:

... given such teachings, that I readily took the blame for the disastrous situation in which I found myself. My understanding of my religion offered me little solace. Indeed, by encouraging self-blame, it deprived me of a sense of injustice ... of being the injured one. (Magona 1992:18)

Indeed, it is often the double-edged sword of spiritual conviction that when one disobeys biblical precepts that personal and often social condemnation results.

Yet when her husband abandons her and their three children, she sees his forfeiture of family responsibility as her unexpected moment of liberation. Her poetic imagination pens these words: 'Wife! Thank God, he left. Soon, misgiving flowered. And, soon thereafter, I bloomed!' (Please, Take Photographs 2009:55). For Magona, her relinquishment of marriage became synonymous with a spiritual experience. She writes of visiting the beach with friends, her first moment of relaxation following her husband's abandonment and the birth of her third child. As she steps into the waters, her wedding ring begins to slip off her finger. She grabs for it, but, in a moment of epiphany, realises that the circle of unity, love and commitment symbolised by the gold band has disintegrated and thus she is released from its useless constraints. Thus, she lets her ring disappear in the cleansing waves of the Pacific Ocean. Magona expresses this nearbaptismal experience in spiritual terms as a death to life: 'On that first day of a brand new year, in my twenty-fourth year of life, in the agitating blue waters, I was born anew' (Magona 1992:13).

Despite this moment of exhilaration, the overwhelming burden of caring for three tiny children compels her to contemplate suicide. She describes the experience as follows:

On a sluggish greyish day in August, the month of my birth, I found myself on the bridge on the Klipfontein road overlooking the railway line in Guguletu. I had left the house very early before any of the children were up. I had also left without the breakfast we couldn't have. There was nothing in the house. Not one grain of corn! ... How long I stood there dully contemplating 
jumping at the sight of an approaching train, I don't know. (Magona 1990:169)

Yet at that moment of desperation, she recalls the spiritual advice of her father: 'The doors of a church are never locked ... because whenever anyone should need a haven, physical or spiritual, God's house should be there, waiting and available'. Magona sought that comfort.

In that church, that evening, I cried; and I prayed. Both activities were no strangers to me. I have, since then, known both, together and separately. There I received strength from God. (Magona 1990:170)

This moment of intercession appears to be an important event for Magona and, although her struggles to regain her economic footing did not immediately lessen, they became more focused, eventually landing her another teaching post. With this elevation in confidence, finances and status, Magona became active in local and national efforts to address the social injustices facing women, particularly black women, which ultimately led to her applying for and receiving a scholarship to Columbia University in New York to complete her master's degree in social work. While there she obtained a post at the United Nations, working as an interpreter for the anti-apartheid radio programme, an employment which covered the next 20 years.

Yet still Magona writes of her spiritual gratitude for the amazing turn her life has taken, acknowledging in prayer what God has done for her (Magona 1992:227). She even reaches out to the indigent husband who had abandoned her so many years earlier, paying for his trip to Cape Town to say farewell to his children who would be relocating to America with her. To prevent him from looking tattered and worn, she went so far as to purchase him new clothes so he would not look like a pauper in front of his children. She writes: 'Without my ever taking a conscious decision, I had let go even of my anger towards him. I had long forgiven him. I'd just not known that I had' (Magona 1992:228). She, in fact, sees his desertion as evidence of God's divine intervention:

Throughout his stay, I looked at my husband and realised, not for the first time, how lucky I was that he had left me. Had we stayed together, I doubt I'd still be alive. (Magona 1992:228)

Yet her ability to offer unmerited favour is not extended with impunity, especially in the face of apartheid's cruelty. Magona, in a 1990 interview, years before the death of Amy Biehl or the construction of her acclaimed novel Mother to Mother, stated:

I think it is good to forgive; this is a hallmark of civilization. But frankly, I cannot forget the stunting of my own life and the lives of other blacks. How can you not hurt? How can you be expected to forget the killing of one's beauty and the promise that lies within that beauty as a child of God? Yes, I'm for the forgiving, but not for the forgetting. (Mattera 1990:11)

Later in her second autobiography Magona reflects on the aching similarities between the histories of black Americans and South Africa, and she resorts to prayer once again, bridging the divine and the temporal with petition for transformation:

Please, dear God, as apartheid crumbles, wipe away the scars of the past. Empower those who have suffered. Let them outgrow the hurt done them. Let them flourish from even such a crushed, emaciated past as theirs. Let them grow, despite the fact of their having been deliberately stunted for centuries. (Magona 1992:217)

Nor is it only in her autobiographies that Magona explores the interplay of Christianity and African traditional religion. Her first fictional work, Mother to Mother, provides an intimate representation of an anguished mother trying to come to terms with her son's murder of a white woman. Magona relates that she was compelled to write the story once she learned that she personally knew one of the murderers' mothers, having grown up with her in the townships, but also because she knew of her own son's vulnerability to commit such violence. She explains:

... but by the grace of God, it could have been my own son who killed Amy Biehl. Why was it her son and not my son? Why was I so fortunate? It's because of episodes like that that I continue to write. (Koyana 2004:155)

In dissecting the seething racial hatred that exploded in this 1993 tragedy, Magona narrates through the paternal grandfather's iintsomi, the story of Nongqawuse's prophesy, which prompted the isiXhosa cattle killing of 1856-1857. Magona's character Mandisa explains the century-old driving force of this spiritual vision:

Nongqawuse saw it in a long ago dream: A great raging whirlwind would come. It would drive abelungu to the sea. Nongqawuse had but voiced the unconscious collective wish of the nation: rid ourselves of the scourge ...

Thus Mxolisi, the killer, became 'the blind sharpened arrow of the wrath of his race' (Magona 1998:210). By including Nongqawuse's prophesy, Magona is able to perform two significant narratorial actions: she can re-enter the history from the colonial voice, which deemed the cattle killing superstitious foolishness, to the African nucleus that respects and reverences the ancestral voice offering a miraculous solution to the white incursion (Iannaccaro 2014). Furthermore, she is able to explain how 'a traumatised history of subjugation had prepared the youth to fight' (Shober 2014). Yet even in this tale, Magona provides her character with the soothing comfort and support of her Methodist church friends and pastor who arrange a meeting between Mandisa, the grief-stricken mother and her frightened, repentant son Mxolisi, who faces imprisonment and possible execution for his violent act.

Her second fictional novel explores the relational impact of AIDS on South African marriages. Through the suffering and death of Beauty, one of their close female friends, the remaining four women discover the tormented nature of the compromised marital bed in the face of this virulent disease. Through this timely novel, Magona illustrates that the road to a black South African woman's autonomy is 
fraught with many obstacles, many of them coached by spiritual proscriptions of a woman's obedience. When her family members are unable to force Amanda's compliance and acquiescence to her husband's infidelity, the sisters-inlaw turn to religious dogma, suggesting that forgiveness is a divine command and hinting that 'love covers a multitude of sins'. It is intimated that if Amanda would not respect the cultural tradition of a man's right to any woman's body, perhaps she will submit to the colonial values of Christianity. Even her husband, Zakes, uses this ploy although he himself is not religious: 'Amanda, you go to church every Sunday. You must have forgiveness in your heart!' (Magona 2008:146). But Amanda refuses, honouring the spiritual notion of forgiveness, but refusing to submit to the confines of a marriage where trust is destroyed: 'I have forgiven him, but the marriage is dead' (Magona 2008:150). Neither Christian dogma nor cultural traditions will compel her to return to a potentially lethal marriage. In fact, Beauty's clarion call to her sisters do not die a stupid death (Magona 2008:74), caused by misplaced trust and ignorance, turns her into a prophetess. Edith, one of the five firm friends, describes Beauty's courage in these spiritual terms:

God in action. The Almighty uses us, plain ordinary people, when we are willing to be instruments of His will. Through her own suffering, Beauty found the courage to save us from a similar fate. And that is grace. (Magona 2008:75)

It is for this reason that the Italian translation of Beauty's Gift is titled This Is My Body, signifying the almost Christ-like sacrifice that Beauty made in surrendering her body to death so her friends could live.

Magona's third fictional work, Chasing the Tails of My Father's Cattle, transports the reader to the rural areas of South Africa's Eastern Cape village of Zenzele, circa 1939. A young Miseka has finally birthed a living child, after nine stillbirths and, although dying in the process, whispers life over her child, naming her 'Shumikazi' as opposed to 'Nokufa' (Mother of Death) that the maternal grandmother wished to bestow upon her. Nonetheless, death seems to follow the youngster to such an extent that witchcraft is suspected and Shumikazi is viewed by the villagers as a harbinger of evil. Even though the visitation by a snake is viewed by some isiXhosa as a positive sign of ancestral blessing (Jordan 1981), when a snake curls itself around the young Shumikazi, the suspicious villagers view it as a malevolent omen. Added to this stigma is the death of three of her cousins who presumably eat from the same cooking pot as she does or the cousin who drowns while trying to save her. Furthermore, when her father's kraal and harvest is bountiful, jealous family members perceive it to be the work of witchcraft although Jojo, her father, insists it is his own hard work that produces this abundance. In this novel, Magona is critical of the narrowminded suspiciousness of a bitter community that sees blessings as a portent of evil rather than attributing them to either God's goodness or simple good fortune. She does, however, promote the isiXhosa concept of Ubuntu, which is described by Michael Battle in his book Reconciliation: The Ubuntu Theology of Desmond Tutu as having:

... a proper self-assurance that comes from knowing they belong to a greater whole, a knowing that they are diminished when another is humiliated, is tortured, is oppressed, is treated as if they were less than who they are. (1997:35)

Battle adds that 'destinies are locked inextricably to one another's' (1997:35), concepts that have strong roots in African spiritualism. She also offers comfort in the ethereal voice of a deceased mother who through her wisdom and encouragement guides the often ostracised and lonely child, soothing the ravages of the youngster's beleaguered heart with her prophetic presence (Rossouw 2016). Through the authentic portrait of African rural life, Magona is able to meaningfully explore African tradition and spirituality at its best and worst.

Almost four decades ago, Nigerian feminist author and critic Buchi Emecheta (The Joys of Motherhood 1979) wrote this prayer: 'God, when will You create a woman who will be fulfilled in herself, a full human being, not anybody's appendage?'. South African writer Sindiwe Magona seems to be that woman. Having dealt with the scars inflicted from past oppression and rejection, she has forged her identity and crafted her autonomy under the secure protection of the Trinity and her ancestors. She deems herself divinely placed in history to leave her mark and light a path for other travellers. By the manner of her living, as she articulates in her poem 'Being' (Please, Take Photographs 2009:15), Magona has harmonised spiritually and creatively, her tenets of faith, restoring the dignity of herself and her African and global sisters, to carve a legacy of liberation hard fought and well deserved.

\section{Conclusion}

Through its explication of Sindiwe Magona's autobiographies and fictional works, this study has sought to investigate the integration of Magona's Christian faith and African spirituality in her literary representations. In recognising the strength of her father's Anglican faith practices as well as the traditional religious practices of her mother in warding off evil and securing the favour and wisdom of her ancestors, Magona acknowledges the cultural and spiritual foundation each afforded her. By incorporating these dual spiritual expressions in her creative works, she illustrates the evidence of these synthesised spiritual practices in establishing identity and autonomy for herself and her characters. She thereby inspires her readers to embrace their religious convictions and to recognise the strength, wisdom and security they offer. This author recommends that the spiritual implications contained within the works of other South African writers be explored as our multi-faith environment offers a rich opportunity to enhance our spiritual identity through these imaginative resources. 


\section{Acknowledgements}

\section{Competing interests}

The author declares that she has no financial or personal relationships that may have inappropriately influenced her in writing this article.

\section{References}

Anderson, A., 2003, Zion and Pentecost: The spirituality and experience of Pentecostal and Zionist/Apostolic churches in South Africa, University of South Africa, Pretoria.

Apostolides, A., 2016, 'South African fantasy: Identity and spirituality', HTS Theological Studies 72(1), https://doi.org/10.4102/hts.v72i3.3255

Ayiedun, A. \& Ordor, A., 2016, 'Integrating the traditional with the contemporary in dispute resolution in Africa', Law, Democracy and Development 20, 155-173, viewed 15 November 2018, from https://doi.org/10.4314/ldd.v20i1.8

Battle, M., 1997, Reconciliation: The ubuntu theology of Desmond Tutu, Pilgrim Press, Cleveland, $\mathrm{OH}$.

Beya, B.M., 2001, 'Women in the Church in Africa: Possibilities for presence and promises', in N.J. Njoroge \& M.W. Dube (eds.), Talitha cum! Theologies of African promises, in N.J. Njoroge \& M.W. Dube (eds.), Talitha cum! The
women, pp. 183-206, Cluster Publications, Pietermaritzburg.

Brittian, A.S., Lewin, N. \& Norris, S.A., 2013, “"You must know where you come from”: South African youths' perceptions of religion in time of social change', Journal of Adolescent Research 28(6), 642-663. https://doi.org/10.1177/0743558413480834

Chiorazzi, A., 2015, 'The spirituality of Africa', Harvard Divinity School, viewed 15 November 2018, from https://hds.harvard.edu/news/2015/10/07/spirituality-africa\#

Cruywagen, D., 2016, The spiritual Mandela, Penguin Random House South Africa, Cape Town

Davies, M., 2017, 'Faith and spirituality in SA - A Huffington Post SA special report', Huffington Post, viewed 31 August 2018, from https://www.huffingtonpost.co. $\mathrm{za} / 2017 / 04 / 10 /$ faith-and-spirituality-in-sa-a-huffington-post-sa-special-repo_a_ 22033123/

De la Porte, A., 2016, 'Spirituality and healthcare: Toward holistic people-centred healthcare in South Africa', HTS Theological Studies 72(4). https://doi.org/10.4102/ healthcare in
hts.v72i 4.3127

Emecheta, B., 1979, The joys of motherhood, Alison and Busby, London.

lannaccaro, G., 2014, 'The story of Nongqawuse in South African twentieth-century fiction', Research Gate, viewed 19 November 2018, from https://www. researchgate.net/publication/318701657

Jordan, A.C., 1981, The wrath of the ancestors, Passeggiata Press, Pueblo, CO.

Joseph, G., 2005, 'Fiction: African fiction and religion', Encyclopedia of Religion, viewed 29 August 2018, from http://www.encyclopedia.com/environment/encyclopediasalmanacs-transcripts-and-maps/fiction-african-fiction-and-religion

King, P.E., 2003, 'Religion and identity: The role of ideological, social, and spiritual contexts', Applied Developmental Science 7, 197-204. https://doi.org/10.1207/ S1532480XADS0703 11
Klaasen, J., 2016, 'Identity, race and faith: The role of faith in post-Apartheid South Africa', HTS Theological Studies 2(2). https://doi.org/10.4102/hts.v72i2.3861

Koyana, S., 2004, Sindiwe Magona: The first decade, University of KwaZulu-Natal Press, Pietermaritzburg.

Levey, D., 2007, 'Religion, literature and identity in South Africa: The case of Alan Paton', Koers 72(1), 65-84. https://doi.org/10.4102/koers.v72i1.192

Lugo, L., 2010, Tension and tolerance: Islam and Christianity in sub-Saharan Africa, Pew Forum on Religion and Public Life, Washington, DC, viewed 29 August 2018, from http://www.pewforum.org/2010/04/15/executive-summary-islam-and-christianityin-sub-saharan-africa/.

Magona, S., 1990, To my children's children, David Philip Publishers, Cape Town.

Magona, S., 1992, Forced to grow, David Philip Publishers, Cape Town.

Magona, S., 1998, Mother to mother, David Philip Publishers, Cape Town.

Magona, S., 2008, Beauty's gift, Kwela Books, Cape Town.

Magona, S., 2009, Please, take photographs, Modjaji Books, Cape Town.

Magona, S., 2015, Chasing the tails of my father's cattle, Seriti sa Sechaba Publishers, Johannesburg.

Marais, B.M. \& Stobie, C., 2014, 'Constructing the autobiographical self, collective identity and spiritual places in South African queer autobiography', Literator 35(1), 9p. https://doi.org/10.4102/lit.v35i1.1081

Martin, C.J., 1993, 'Biblical theodicy and black women's spiritual autobiography', in E.M. Townes (ed.), Troubling in my soul, pp. 13-36, Orbis Books, Maryknoll, NY.

Mattera, D., 1990, 'Forgive, but don't forget the pain', Weekly Mail, 13 December, p. 11.

Mikell, G., 1997, African feminism: The politics of survival in sub-Saharan Africa, University of Pennsylvania Press, Philadelphia, PA.

Mphahlele, E., 1959, Down second avenue, Faber and Faber, London.

Ngcobo, L., 1990, And they didn't die, The Feminist Press, New York, NY.

Njoroge, N.J. \& Dube, M.W., 2001, Talitha cum! Theologies of African women, Cluster Publications, Pietermaritzburg.

Pillay, J., 2017, 'Faith and reality: The role and contributions of the ecumenical church to the realities and development of South Africa since the advent of democracy in 1994 ', HTS Theological Studies 73(4), viewed 18 November 2018, from https://doi. org/10.4102/hts.v73i4.4519

Pillay, V., 2013, 'Mandela and the confessions of a closet Christian', Mail and Guardian, viewed 27 March 2018, from https://mg.co.za/article/2013-12-12-mandela-andthe-confessions-of-a-closet-christian

Rossouw, R., 2016, 'Book reviews: Chasing the tails of my father's cattle and little suns', Business Day, viewed 19 November 2018, from https://www.businesslive. co.za/bd/life/books/2016-02-12-book-reviews-chasing-the-tails-of-my-fatherscattle-and-little-suns/

Shober, D., 2014, Climbing higher: The literary life of Sindiwe Magona, New Africa Books, Cape Town.

Shober, D., 2017, 'Ecofeminist invitations in the works of Sindiwe Magona', Literator 38(1), 10p. https://doi.org/10.4102/lit.v38i1.1392

Thomas, L.E., 1997, 'Christinah Nku: A woman at the center of healing her nation', in Townes, E.M. (ed.), Embracing the spirit: Womanist perspectives on hope, salvation and transformation, pp. 54-71, Orbis Books, Maryknoll, NY. 